\title{
Contribution to the bryophyte flora of Svalbard: hepatics of Barents Island
}

\author{
Nadezhda Konstantinova \& Anatoliy Savchenko \\ Polar-Alpine Botanical Garden Kola Sci. Center Russian Academy of SCI, 184256 KIROVSK, Russia \\ E-mail: nadya50@list.ru
}

\begin{abstract}
The annotated list of hepatics of Barents Island (Svalbard archipelago) was compiled based on the collections by Savchenko, literature data and Arne Frisvoll's collection in TRH. A total of 35 species, three subspecies and four varieties are recorded for Barents Island. Fifteen taxa are listed as new for Barents Island and four taxa are listed as new for Svalbard, including Lophozia silvicola, Lophozia subapiculata, Preissia quadrata subsp. hyperborea and Lophoziopsis excisa var. elegans. A new combination Trilophozia quinquedentata var. turgida is made. Annotations to the species include distribution, description of habitats, and some morphological characteristics of the studied specimens. Peculiarities of the hepatic flora of the island and the distribution in Svalbard are discussed.
\end{abstract}

Keywords: taxonomy, distribution, phytogeography, reproduction, ecology

\section{INTRODUCTION}

Barents Island (Barentsøya) is one of the five largest islands of the Svalbard archipelago with an area of 1288 square kilometres (https:// en.wikipedia.org/wiki/Barentsøya). It is situated in the eastern part of the archipelago between Western Spitsbergen Island and Edge Island. Approximately half of the area is covered by glaciers. Barents Island lies within NordwestSpitsbergen National Park, so it is important to study the diversity of different groups of the island, including species occurrence, abundance and their dispersal abilities.

Philippi (1973) provided the first extensive data on hepatics of Barents Island. In his comprehensive study of the bryophyte flora and vegetation "des Freeman-Sund-Gebietes" of Svalbard (1.c.) he cited 22 species of hepatics for the southern part of the island. In 2011, the second author collected hepatics in the northern part of the island (Fig. 1). The specimens gathered were identified by the first author. They include numerous additions to the hepatic flora of the island. In 2016, during a revision of Frisvoll's collection preserved in TRH we found one more newly recorded species occurring on Barents Island. Among the species that we list from Barents Island there are a number that were reported by Frisvoll and Elvebakk (1996) to be rare or very rare in Svalbard as well as four taxa that were not previously reported for Svalbard.
Because the distribution of hepatics in Svalbard is insufficiently known our aim was to produce an annotated list of hepatics of Barents Island.

\section{MATERIAL AND METHODS}

The compiled list of species is mainly based on results of identification of specimens collected by the second author in the northern part of Barents Island during four days from the 3rd to 6th August 2011 (Fig. 1). For all localities the coordinates and elevations were measured using GPS (Table 1.). In total 80 specimens from 22 sites were collected and later identified by the first author. The specimens are deposited in the Herbarium of the Polar-Alpine Botanical Garden-Institute of the Kola Scientific Center, Russian Academy of Sciences (KPABG). Label data are incorporated in the Cryptogamic Russian Information System (CRIS) and are available at http://kpabg.ru/h/. In 2016 we studied some specimens in TRH collected by Rolv Hjelmstad and identified by Frisvoll. They have also been included in this paper. We have also included data on the distribution of the species in the southern part of Barents Island (Fig. 1, Table 1) reported by Philippi (1973). The habitat descriptions from the latter publication were added - partly in German (original text, to be more exact), partly in English (by shortening the text). 


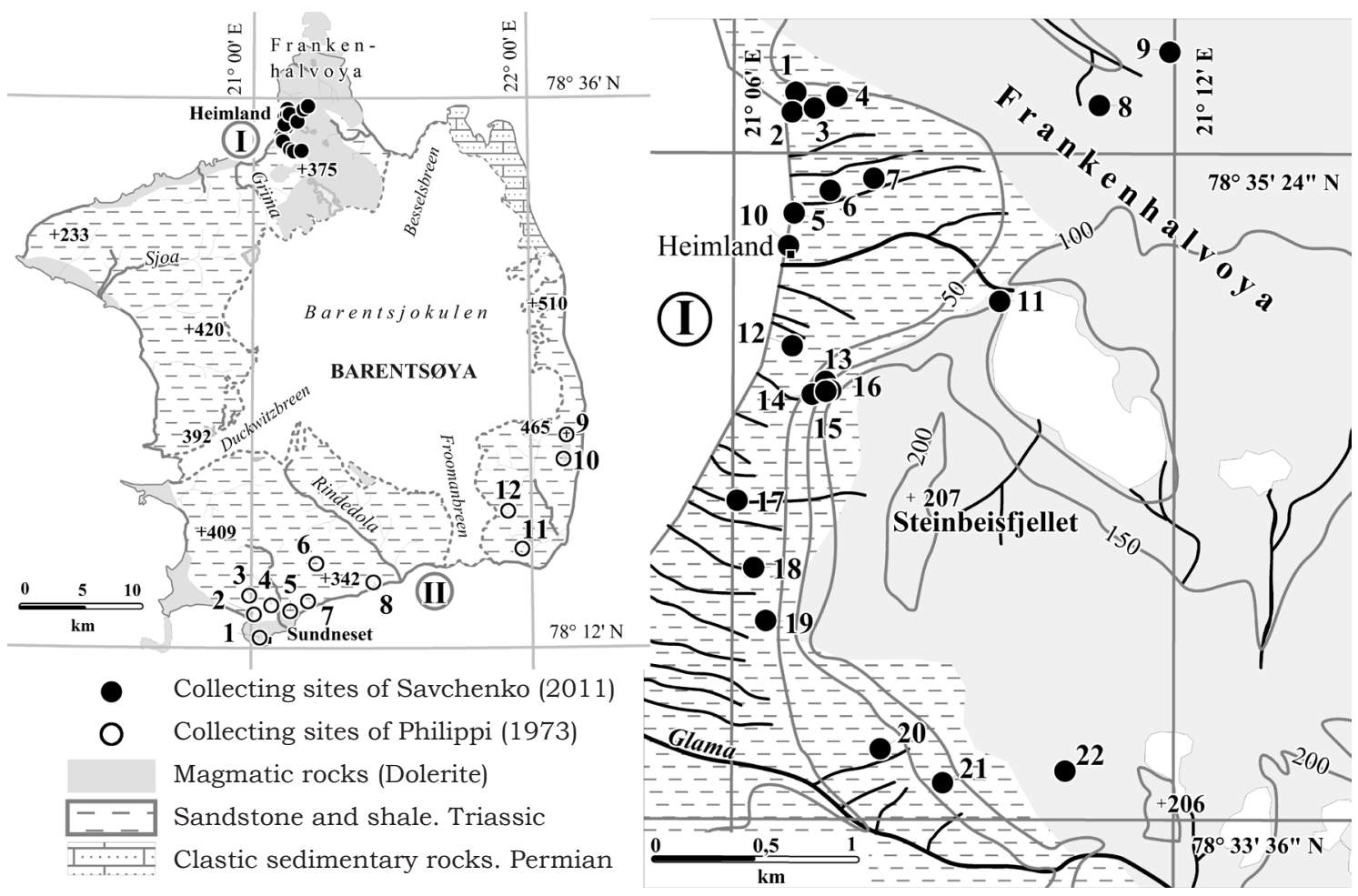

Fig. 1. Collection localities (details in Table 1).

\section{ANNOTATED LIST OF SPECIES}

The annotated list of hepatics includes 35 species, two subspecies and five varieties. The nomenclature generally follows Söderström et al. (2016) with changes for some Lophozia species. We treated Lophozia longiflora as an accepted and distinct species following Bakalin (2016). Some synonyms that are common in publications on Svalbard are cited in square brackets. Brief descriptions of each species are in accordance with those that have been applied for the hepatics of Nordaustlandet (Konstantinova \& Savchenko, 2012). Following the species name the reproductive structures, if present, are provided in parentheses (i.e., and. = androecia; gyn. = gynoecia; per = perianths or pseudoperianths; spor. $=$ sporophytes; gem. $=$ gemmae) . The numbers of collecting localities are listed according to that given in the Table 1. For more common species the habitat characteristics and frequencies are given with the link (in square brackets) to at least one specimen in CRIS (http:/ / kpabg. $\mathrm{ru} / \mathrm{h} /$ ), for rare species collected from 1-3 locali- ties the links to CRIS for all studied specimens are provided. Taxa reported for the first time for Barents Island are marked with an asterisk, taxa reported for the first time for Svalbard are marked with two asterisks.

ARnellia FEnNica (Gottsche) Lindb. - II: 1, 4, 5. Sporadic in Tomenthypnum-Tundren (with Hypnum revolutum) or in Dryas octopetala-wasteland (Philippi, 1973: 9).Relatively rare in Svalbard (Frisvoll \& Elvebakk, 1996).

ANEURA PINGUIS (L.) Dumort. (per., and.). - I: 12, 17,19 . At the edge of a mire on the coastal plain, on peat and soil between boulders on sea terraces [119690]. Quite common and sometimes abundant, often mixed with mosses. The most common associate hepatics are Blepharostoma trichophyllum subsp. brevirete, Cephaloziella varians, Schljakovianthus quadrilobus, and Mesoptychia heterocolpos. It occurs more rarely with Lophoziopsis polaris, Jungermannia polaris, Odontoschisma macounii, Scapania obcordata, and S. cuspiduligera. II: 1, 5. Sporadic in moist and wet places (Philippi, 1973). Widespread in 
Table 1. Description of localities studied on Barents Island

\begin{tabular}{|c|c|c|c|}
\hline Locality & Description & Coordinates & $\begin{array}{l}\text { Elevation } \\
\text { (m a.s.l.) }\end{array}$ \\
\hline & \multicolumn{3}{|l|}{ I - localities studied by A.N.Savchenko in northern part of Barents Island } \\
\hline 1 & Heimland, at the bottom of the southern slope of dolerite plateau. In the bog. & $78^{\circ} 35^{\prime} 34^{\prime \prime} \mathrm{N} 21^{\circ} 6^{\prime} 51^{\prime \prime} \mathrm{E}$ & 10 \\
\hline 2 & Heimland, moist tundra at the bottom of the southern slope of dolerite plateau. & $78^{\circ} 35^{\prime} 31^{\prime \prime} \mathrm{N} 21^{\circ} 6^{\prime} 48^{\prime \prime} \mathrm{E}$ & 1 \\
\hline 3 & $\begin{array}{l}\text { Heimland, at the bottom of the southern slope of dolerite plateau, moist tunfra } \\
\text { with non sorted circles and mad boils between two brooks. }\end{array}$ & $78^{\circ} 35^{\prime} 31^{\prime \prime} \mathrm{N} 21^{\circ} 7^{\prime} 6^{\prime \prime} \mathrm{E}$ & 14 \\
\hline 4 & Heimland, moist area at the bottom of the southern slope of dolerite plateau. & $78^{\circ} 35^{\prime} 33^{\prime \prime} \mathrm{N} 21^{\circ} 7^{\prime} 24^{\prime \prime} \mathrm{E}$ & 16 \\
\hline 5 & Heimland, north faced left bank of stream, ca. $50 \mathrm{~m}$ from the coast of sea. & $78^{\circ} 35^{\prime} 14^{\prime \prime} \mathrm{N} 21^{\circ} 6^{\prime} 49^{\prime \prime} \mathrm{E}$ & 5 \\
\hline 6 & Heimland, south faced right bank of stream. & $78^{\circ} 35^{\prime} 18^{\prime \prime} \mathrm{N} 21^{\circ} 7^{\prime} 19^{\prime \prime} \mathrm{E}$ & 5 \\
\hline 7 & $\begin{array}{l}\text { Heimland, dry Luzula-grass moss community covered folds of ground between } \\
\text { streams. }\end{array}$ & 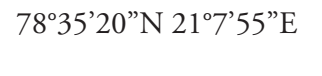 & 19 \\
\hline 8 & $\begin{array}{l}\text { Central part of Frankenhalvøya Peninsula, dolerite plateau, dolerite cliffs with } \\
\text { cracks along right south facing bank of stream. }\end{array}$ & $78^{\circ} 35^{\prime} 32^{\prime \prime} \mathrm{N} 21^{\circ} 10^{\prime} 59^{\prime \prime} \mathrm{E}$ & 69 \\
\hline 9 & $\begin{array}{l}\text { Central part of Frankenhalvøya Peninsula, dolerite plateau, valley of stream, } \\
\text { tundra with loamy partly covered by bryophytes and grasses frost boils on ter- } \\
\text { race on right bank of river. }\end{array}$ & $78^{\circ} 35^{\prime} 41^{\prime \prime} \mathrm{N} 21^{\circ} 11^{\prime} 56^{\prime \prime} \mathrm{E}$ & 46 \\
\hline 10 & Heimland, coast of sea, north faced left bank of stream, near cabin. & $78^{\circ} 35^{\prime} 9^{\prime \prime} \mathrm{N} 21^{\circ} 6^{\prime} 45^{\prime \prime} \mathrm{E}$ & 5 \\
\hline 11 & $\begin{array}{l}\text { Steinbeisfellet, on plateau at the bottom of the height } 207 \mathrm{~m} \text {, dolerite rock } \\
\text { outcrops on bank of lake. }\end{array}$ & $78^{\circ} 35^{\prime} 0^{\prime \prime} \mathrm{N} 21^{\circ} 9^{\prime} 38^{\prime \prime} \mathrm{E}$ & 104 \\
\hline 12 & At the bottom of western slope of Steinbeisfellet Mountain, watterloged area. & $78^{\circ} 34^{\prime} 53^{\prime \prime} \mathrm{N} 21^{\circ} 6^{\prime} 48^{\prime \prime} \mathrm{E}$ & 17 \\
\hline 13 & Covered by grass turfs steep western slope of Steinbeisfellet Mountain. & $78^{\circ} 34^{\prime} 47^{\prime \prime} \mathrm{N} 21^{\circ} 7^{\prime} 15^{\prime \prime} \mathrm{E}$ & 106 \\
\hline 14 & Steep western slope of Steinbeisfellet Mountain. & $78^{\circ} 34^{\prime} 45^{\prime \prime} \mathrm{N} 21^{\circ} 7^{\prime} 5^{\prime \prime} \mathrm{E}$ & 78 \\
\hline 15 & Sandstone steep western slope of Steinbeisfellet Mountain. & $78^{\circ} 34^{\prime} 46^{\prime \prime} \mathrm{N} 21^{\circ} 7^{\prime} 20^{\prime \prime} \mathrm{E}$ & 138 \\
\hline 16 & Steep western slope of Steinbeisfellet Mountain. & $78^{\circ} 34^{\prime} 45^{\prime \prime} \mathrm{N} 21^{\circ} 7^{\prime} 16^{\prime \prime} \mathrm{E}$ & 114 \\
\hline 17 & $\begin{array}{l}\text { Heimland, watterloged area on bank of brook on western slope of Steinbeis- } \\
\text { fjellet Mountain. }\end{array}$ & $78^{\circ} 34^{\prime} 28^{\prime \prime} \mathrm{N} 21^{\circ} 6^{\prime} 4^{\prime \prime} \mathrm{E}$ & 20 \\
\hline 18 & Heimland, western slope of Steinbeisfellet, shallow brook in watterloged area. & $78^{\circ} 34^{\prime} 17^{\prime \prime} \mathrm{N} 21^{\circ} 6^{\prime} 18^{\prime \prime} \mathrm{E}$ & 24 \\
\hline 19 & Western slope of Steinbeisfellet Mountain, rock stream on terrace. & $78^{\circ} 34^{\prime} 8^{\prime \prime} \mathrm{N} 21^{\circ} 6^{\prime} 27^{\prime \prime} \mathrm{E}$ & 37 \\
\hline 20 & $\begin{array}{l}\text { Valley of Glama Stream at the bottom of southern slope of Steinbeisfellet } \\
\text { Mountain, tundra with frost boils. }\end{array}$ & $78^{\circ} 33^{\prime} 47^{\prime \prime} \mathrm{N} 21^{\circ} 8^{\prime} 1^{\prime \prime} \mathrm{E}$ & 76 \\
\hline 21 & $\begin{array}{l}\text { Valley of Glama Stream at the bottom of southern slope of Steinbeisfellet } \\
\text { Mountain watterloged area under rock stream. }\end{array}$ & $78^{\circ} 33^{\prime} 42^{\prime \prime} \mathrm{N} 21^{\circ} 8^{\prime} 52^{\prime \prime} \mathrm{E}$ & 96 \\
\hline \multirow[t]{2}{*}{22} & Steinbeisfjellet palteau, rock outcrops. & $78^{\circ} 33^{\prime} 44^{\prime \prime} \mathrm{N} 21^{\circ} 10^{\prime} 32^{\prime \prime} \mathrm{E}$ & 192 \\
\hline & $\begin{array}{l}\text { II - Localities studied by Philippi (1973) in the south of Barents Islands } \\
\text { (accordingly Philippi, 1973, in German) }\end{array}$ & & \\
\hline 1 & Talavera-Vorland: Basalte und marine Sediment. & & \\
\hline 2 & $\begin{array}{l}\text { Vogelweide: an die Talavera nach } \mathrm{N} \text { anschließend. Steiler Südhang mit Ba- } \\
\text { saltfelsen. }\end{array}$ & & ca. 200 \\
\hline 3 & $\begin{array}{l}\text { Krefftberg: vegetationsarme Hochfläche mit einigen Basaltblodthalden nahe } \\
\text { des Gipfels. }\end{array}$ & & 360 \\
\hline 4 & $\begin{array}{l}\text { Helisberg an die Talavera nach N anschließend, von der Vogelweide durch den } \\
\text { Einschnitt des Vogelweidebaches getrennt; steiler Südhang. }\end{array}$ & & 180 \\
\hline 5 & $\begin{array}{l}\text { Seelisberg: an die Talavera nach N anschließend vom Helisberg durch den Ein- } \\
\text { schnitt des Stauferbaches getrennt. Steiler Südhang mit einzelnen Basaltfelsen, } \\
\text { auf der Hochfläche zwei Seen (122 und } 130 \mathrm{~m} \text { hoch). }\end{array}$ & & Ca. 200 \\
\hline 6 & Hohenstaufen & & 440 \\
\hline 7 & $\begin{array}{l}\text { Hahnenkamm: an den Seelisberg nach E anschließend; besuchte Stellen am } \\
\text { Westhang. }\end{array}$ & & $150-250$ \\
\hline 8 & Scharfreiter: Fuß nahe der Küste. & & \\
\hline 9 & Jeppeberg Basalthochfläche. & & 460 \\
\hline 10 & Südfuß des Jeppeberges. & & \\
\hline 11 & Büdelberg & & 298 \\
\hline 12 & $\begin{array}{l}\text { Murnautal (vom Murnaugletscher, emer Seitenzunge des Freemangletschers, } \\
\text { abgehend). }\end{array}$ & & 298 \\
\hline
\end{tabular}


Svalbard, usually occurs in rather scattered populations. Occurs abundantly in rare cases (at a single station on Barents Island).

AnTHElia JURATZKANA (Limpr.) Trevis. (spor.) - I: I3, $6,18,19,21$. On edges of mud boils, frost scars and polygons in cryogenic tundras with non sorted circles and mud boils at the bottom of slopes, in cracks in steep peaty banks of streams, between boulders in block screes. In pure mats or mixed with Blepharostoma trichophyllum subsp. brevirete, Lophozia spp. and Cephaloziella varians [119729]. II: 1, 3, 6, 9. Frequent (Philippi, 1973). One of the most common species in Svalbard.

BARBILOPHOZIA HATCHERI (Evans) Loeske (gem.) I: 19. On soil, between boulders, in pure mats [119721] or with Ptilidium ciliare [1 19723]. II: 1, 3, 5. Sporadic in basalt screes (Philippi, 1973). Common in Svalbard, mostly in areas with block screes.

Blepharostoma trichophyllum (L.) Dumort. subsp. BREVIRETE (Bryhn et Kaal.) R.M.Schust. - I: 2, 3, 5, 6, 7, 8, 12, 17, 18, 19, 21. On soil mixed with other bryophytes in boggy areas at the base of slopes, on peat along sides of streams as well as on hummocks in watercourses, on soil between boulders in block screes, on spots of bare soil in spotty tundras on slopes [119677]. It sometimes dominates in bryophyte mats or occurs mixed with other bryophytes. The most frequent associates are Aneura pinguis, Cephaloziella varians, Lophoziopsis polaris, and Schljakovianthus quadrilobus. Reported as very common by Philippi (1973), but without listing collecting sites. All Blepharostoma trichophyllum specimens studied by Philippi (1.c.) were referred to this variety. Blepharostoma trichophyllum subsp. brevirete is one of the most common taxa in Svalbard. Arnell (in Arnell \& Mårtensson, 1959) and Rejment-Grochowska (1967) supposed that the species is present in Svalbard exclusively by the arctic subspecies brevirete. But Karczmarz \& Święs (1990) and Święs \& Karczmarz (1991a,b, 1993) reported both subspecies brevirete and the typical subspecies.

*Bucegia Romanica Radian - I: 5: coastal valley, on banks of dry rivulet, some thalli with young male receptacles [117105] with Lophoziopsis polaris, and Blepharostoma trichophyllum subsp. brevirete. Recently found in many sites in Svalbard (Konstantinova et al., 2014).
Cephalozia ambigua C.Massal. - I: 18. On peat hummocks in a shallow stream [119715] mixed with Blepharostoma trichophyllum subsp. brevirete, Lophoziopsis polaris, Scapania obcordata, and Trilophozia quinquedentata. II: 3, 10. Rare on lime-poor snowbeds (Philippi, 1973). One of the most common hepatics in Svalbard, but rare in the studied area. It is treated as a variety or subspecies of C. bicuspidata by some authors (Schuster 1969; Damsholt, 2002), but we prefer to keep it separate until treatment of this group has been more or less established (see also Vilnet et al., 2011). The specimens with small cells were referred by us to Cephalozia ambigua, whereas the one with large cells to Cephalozia bicuspidata.

*Cephalozia Bicuspidata (L.) Dumort. - I: 7. In Luzula-grass moss tundra [119689] in cracks, on soil, sporadic in mats dominated by Lophozia wenzelii, Sphenolobus minutus, and Cephaloziella varians. Only a few plants were found in the sample. The shoots are very small, just $260-280$ $\mu \mathrm{m}$ wide with distinct large underleaves, cells on the lateral side of shoots large, 30-37 $\mu \mathrm{m}$ wide, leaf cells $24-30 \times 26-37$ (40). 13. On a steep slope under sandstone cliff [119696], in peat niches, among mosses and lichens. The presence of small to very large underleaves in Cephalozia bicuspidata s. lat. was noted by Schuster (1988: 179). Such forms of Cephalozia bicuspidata were probably referred to Pleurocladula albescens by Frisvoll \& Elvebakk (1996) who regarded it (1.c.) as widespread in Svalbard, but we only collected it once (Konstantinova \& Savchenko, 2008b). It is noticeable that we did not find any specimens identified as Pleurocladula albescens in Frisvoll's Svalbard collections in TRH.

Cephaloziella varians (Gottsche) Steph. [Cephaloziella arctica Bryhn \& Douin)] - 2, 3, 5, 7, 8, $9,13,16,17,19,20,21,22$. The most common species in the studied area. Without gemmae, perianths or androecia. Occurs on soil under rocks and in different types of tundras, especially in spotty tundras, among mosses on slopes, on boggy terraces, on banks and in watercourses of temporary streams; both in pure mats or mixed with other bryophytes [119730]. The most common hepatic associates are: Blepharostoma trichophyllum subsp. brevirete, Lophoziopsis polaris, Schljakovianthus quadrilobus, and Trilophozia quinquedentata, all of them widespread in the archipelago. 
*Clevea hyalina (Sommerf.) Lindb. [Athalamia hyalina (Sommerf.) S.Hatt.] (spor.) - The species was found during the study of the TRH specimens: $78.6298 \mathrm{~N}, 21.3121 \mathrm{E}, 670383 / 1$, collected by Rolv Hjelmstad 18-08-1977, determined by A. Frisvoll as Hepatica, TRH, two thalli. Does not seem to be rare in Svalbard (cf. Konstantinova \& Savchenko, 2012), but mostly occurs as single thalli and is probably often confused with other species, particularly Preissia quadrata.

Gymnomitrion concinnatum (Lightf.) Corda - I: 3. At the base of slopes, tundra with cryogenic non sorted circles and mud boils, the edge of circles and boils, in small crack at the edge of sample dominated by Lophozia wenzelii [119675]. II: $2,3,5,6,9,11$. Not rare in altitudes from 250 to $460 \mathrm{~m}$ (Philippi, 1973). Characterized as "scattered or common, at least locally in Svalbard" (Frisvoll \& Elvebakk, 1996). That is also supported by our study (Konstantinova $\&$ Savchenko, 2008). Mostly restricted to acidic sites, which explains its rare occurrence in the north of Barents Island.

Gymnomitrion corallioides Nees - I: 3 . At the base of slope, tundra with cryogenic non sorted circles and mud boils, the edge of circles and boils, on the edge of mud boils, in small cracks, small pure cushion with admixture of Lophozia wenzelii and Sphenolobus minutus [119676]. II: 1, 3, 6, 9. "Auf trockener, kalkarmer Erde" (Philippi, 1973). There are several specimens of this species in TRH collected by Rolv Hjelmstad (69822/1, 09-08-1977 and 69821/1, 2907-1977). One of the most common species in Svalbard.

*JungeRMANNIA POLARIS Lindb. (per., and.) - I: 17. On peat in niches of the steep south facing bank of a brook [119710, 119740], prevails in mats with admixture of Lophoziopsis polaris, Trilophozia quinquedentata, and Preissia quadrata and at the edge of a bog [119709], some shoots in mats dominated by Aneura pinguis. Rather widespread in Svalbard according to our data, usually occurs as admixture in mats of other bryophytes.

*LOPHOZIA MURMANICA Kaal. [Lophozia wenzelii (Nees) Steph. var. groenlandica (Nees) Bakalin] (gem.) - I: 7. In Luzula-grass moss tundra [119689] in cracks, on soil among mosses, with admixture of Cephaloziella varians, Sphenolobus minutus, and Trilophozia quinquedentata. 18. On peat on bank of a dried up creek [119717], mixed with Blepharostoma trichophyllum subsp. brevirete, Lophoziopsis propagulifera, and Anthelia juratzkana.

**LopHOZIA SILVICOLA H.Buch [Lophozia ventricosa (Dicks) Dumort. var. silvicola (H.Buch) E.W.Jones] (gem.) - I: 7. In Luzula-grass moss tundra [119688] in cracks, on soil among mosses, sporadic in mats dominated by Sphenolobus minutus or Dicranum sp. and admixture of Cephaloziella varians, Trilophozia quinquedentata, and Blepharostoma trichophyllum subsp. brevirete. Plants with boil-shaped piles of gemmae on lobes of upper most leaves, biocentric 8-15 per cell oil bodies, small trigones characteristic for the species. Treated as a variety of $L$ ventricosa by some authors (Damsholt, 2002), recorded as not rare in Svalbard (Frisvoll \& Elvebakk, 1996). Different interpretations of the name $L$. ventricosa makes it impossible to distinguish the distribution of these two taxa in Svalbard without revision of the group. This record of Lophozia silvicola is the first one in Svalbard.

**LopHOZIA SUBAPICULATA R.M.Schust. et Damsh. (gem.) I: 7 - in Luzula-grass moss tundra [119689] in cracks, on soil among mosses, with admixture of Cephaloziella varians, Sphenolobus minutus, and Trilophozia quinquedentata. The studied plants fit well with the description of the species in Schuster (1974: 104-107): plants are small with shoots ca. 1-1.2 mm wide, leaves distinctly longer than wide $(600-730 \times 700-800 \mu \mathrm{m}$ wide as long), with characteristically brownish to red-brownish colored leaf margins and noncolored ventral base and gibbous sinuses that vary from 0.25 to 0.45 leaf length, but differs in that from Schuster's description (1.c.) who says "sinus descending 0.2-0.25". The most striking feature of the species is the apices of the lobes that can end in one clearly elongate cell or two superposed cells. We prefer to recognize this critical taxon as a separate species because of its quite distinct appearance and occurrence in the high arctic.

LOPHOZIA WENZELII (Nees) Steph. var. LAPPONICA H.Buch et S.W.Arnell (gem.) - I: 3. At the bottom of a slope, in tundra with cryogenic non sorted circles and mud boils, in crevices on the edge of a circle [119675] with admixture of Sphenolobus minutus, Anthelia juratzkana, and Gymnomitrion corallioides. 7. In Luzula-grass 
moss tundra [119689] in cracks, on soil among mosses, with admixture of Cephaloziella varians and Sphenolobus minutus.

*LopHOZIOPSIS EXCISA (Dicks.) Konstant. et Vilnet var. EXcisa [Lophozia excisa (Dicks.) Dumort.] (gem., and., gyn.). - I: 14. Between rocks at the base of a slope [119728], mixed with Anthelia juratzkana. Collected plants are clearly paroicous with thin-walled cells characteristic for the species and red gemmae of characteristic shape. Excluded from Svalbard's flora by Frisvoll \& Elvebakk (1996), but we collected it in Svalbard many times (Konstantinova \& Savchenko, 2008a; unpublished data).

**LOPHOZIOPSIS EXCISA var. ELEGANS (R.M.Schust.) Konstant. et Vilnet [Lophozia excisa (Dicks.) Dumort. var. elegans R.M.Schust.] (gem., and., gyn.). - I: 16. On a steep solifluction slope, between rocks [119698], on soil under rocks, sporadic, mixed with Cephaloziella varians, Lophoziopsis polaris, and Scapania obcordata. This variety is characterized by fleshy and flattened stem, clear green color with contrasting bright red gemmae that often are three and even four-celled. Whether this taxon merits species status needs to be studied. It is the first record of this poorly known arctic taxon for Svalbard.

*LOPHOZIOPSIS POLARIS (R.M.Schust.) Konstant. et Vilnet [Lophozia polaris (R.M.Schust.) R.M.Schust. \& Damsh.] (gem.) - I: 2, 3, 5, 6, 8, $9,13,16,17,18,19$. On peat and soil in cracks and niches in banks of streams, in bryophyte cushions in tundras with cryogenic non sorted circles and mud boils, and on steep slopes, on soil between rocks in solifluction slopes and near single boulders in tundras, on peat and sandy soil in cracks of dolerite cliffs [119700, 119722]. Occurs sometimes in pure mats (in cracks of dolerite cliffs), but more often mixed with other bryophytes. The most common associates are other hepatics: Blepharostoma trichophyllum subsp. brevirete, Trilophozia quinquedentata, Cephaloziella varians, and Schljakovianthus quadrilobus, all of them widespread in Svalbard. Treated as Lophozia alpestris subsp. polaris by Schuster (1969). All records of Lophozia alpestris (Schleich.) A.Evans for the Barents Island in Philippi (1973) should most likely be referred to this species. Not rare in Svalbard as we stressed earlier (see fig. 3 in Konstantinova \& Savchenko, 2012:), even abundant in some areas such as Barents Island.
*Lophoziopsis cf. RUbRigemma (R.M.Schust.) Konstant. et Vilnet (gem.) - I: 8. North facing dolerite cliffs, mixed with mosses [119743]. 14. Between dolerite blocks, in cracks [119741, 119742], with admixture of Trilophozia quinquedentata and Scapania obcordata. Green to dark and dirty green with abundant dark vinaceous or deep red brown gemmae that are polygonal to quadrate (20)24-30 $\mu \mathrm{m}$, leaf cells (30) 33-37(40)×(30)36-50 $\mu \mathrm{m}$, rarely in some of the uppermost leaves $25-30 \mu \mathrm{m}$ wide. Schuster (1969) stressed that it is hard to distinguish this species from Lophoziopsis polaris without seeing the perianth. Perianth were unfortunately not found in the collected specimens. We previously recorded this species as questionable for the Grønfjord area (Konstantinova \& Savchenko, 2008b). Lophoziopsis rubrigemma is a poorly understood arctic taxon that was treated by Bakalin (2005) as subspecies of Lophoziopsis pellucida (R.M.Schust.) Konstant. et Vilnet, but L. rubrigemma differs from $L$. pellucida both in morphology having dark red to brownish red gemmae whereas yellow-orange in L. pellucida and in ecology being mostly acidophillous vs. the strictly calciphillous $L$. pellucida. We collected L. rubrigemma in several sites in Svalbard, but the taxonomic status of this problematic taxon should be redefined and re-evaluated.

MARCHANTIA POLYMORPHA subsp. MONTIVAGANS Bischl. et Boissel.-Dub. [Marchantia alpestris (Nees) Burgeff] (gem.). - Found during the study of the specimens in TRH: $78.6298 \mathrm{~N}, 21.3121 \mathrm{E}$ collected by Rolv Hjelmstad 21-08-1977, 69398/1, "dike under fuglefjell". II: 1. Rare, in moist, slightly "eutrophierten oder halischen" sites (Philippi, 1973).

*Mesoptychia collaRis (Nees) L.Söderstr. et Váňa [Leiocolea collaris (Nees) Schljakov, Lophozia collaris (Nees) Dumort.] - I: 3. On dolerite northfacing cliffs [119744], mixed with Blepharostoma trichophyllum subsp. brevirete, Cephaloziella varians, and Schljakovianthus quadrilobus var. glareosus. Mesoptychia collaris was excluded from Svalbard's flora by Frisvoll \& Elvebakk (1996), but we have shown earlier (Konstantinova \& Savchenko, 2012) that this species occurs sporadically in Svalbard and differs from both Mesoptychia heterocolpos and M. badensis in the shape of leaves, cell shape, coloration etc.

*Mesoptychia heterocolpos (Thed. ex Hartm.) L.Söderstr. et Váňa var. HETEROCOLPOS [Leiocolea 
heterocolpos (Thed. ex C.Hartm.) H.Buch; Lophozia heterocolpos (Hartm.) Howe ]. - The typical variety was collected only once: I: 11 . At the edge of a bog [119704, 119707, 119708]], mixed with Aneura pinguis, Blepharostoma trichophyllum subsp. brevirete, Cephaloziella varians, and Odontoschisma macounii, Schljakovianthus quadrilobus.

*MESOPTYCHIA HETEROCOLPOS var. HARPANTHOIDES (Bryhn et Kaal.) L.Söderstr. et Váňa [Leiocolea heterocolpos (Thed. ex C.Hartm.) H.Buch var. harpanthoides (Bryhn \& Kaal.) S.W. Arnell] - I: 1. In moist tundra at the base of a slope [119668], mixed with Blepharostoma trichophyllum subsp. brevirete, Cephaloziella varians, Odontoschisma macounii, and Trilophozia quinquedentata. 3. In tundra with cryogenic mud boils, on mud boil [119677], mixed with Blepharostoma trichophyllum subsp. brevirete, Cephaloziella varians, Lophoziopsis polaris, Schljakovianthus quadrilobus, and Trilophozia quinquedentata. 17. At the edge of a mire [119703]. This high arctic variety was recorded for Kongsfjorden (Arnell \& Mårtensson, 1959 as var. arctica (S.W.Arnell) Mårtensson ex S.W.Arnell). We reported it earlier for Nordaustlandet (Konstantinova \& Savchenko, 2012).

Odontoschisma macouni (Austin) Underw. - I: 2: On circles and boils in moist tundra with cryogenic non sorted circles and mud boils at the base of a slope [119670]. 17: At the edge of mires, dominant in mats with admixture of Aneura pinguis, Schljakovianthus quadrilobus, Blepharostoma trichophyllum subsp. brevirete, Cephaloziella varians, and Mesoptychia heterocolpos [19670, 119708]. II: 3, 6. Sporadic and restricted to "Tomenthypnum-Tundren" (Philippi, 1973).

PREISSIA QUAdRATA (Scop.) Nees - II: 1 . „Vereinzelt auf lange schneebedeckten, offenen Erdstellen zwischen Basaltfelsen“ (Philippi, 1973). This record should probably be referred to subsp. hyperborea that was described later (Schuster, 1985) see below.

**PREISSIA QUADRATA subsp. HYPERBOREA R.M. Schust. [and., per.] - I: 2. Several specimens were collected on peat soil along a dried-up brook [119711, 119740, 119713], associates are Lophoziopsis polaris, Cephaloziella varians, Jungermannia polaris, and Scapania gymnostomophila. The specimens are autoicous with male and female receptacles. Male receptacles have wide nitid flange arched upward as it is described in Schuster (1992), but the thalli are not as wide as described (1.c.), usually 5 , rare 6-7 $\mathrm{mm}$ wide. Subsp. hyperborea probably merits to be elevated to species level.

Ptilidium Ciliare (L.) Hampe - I: 2, 7, 17, 19. In non sorted circles and mud boils in tundra, in the bogs, on peat soil between boulders [119714]. The species occurs both in pure mats and mixed with Trilophozia quinquedentata and Barbilophozia hatcheri, sometimes with Blepharostoma trichophyllum subsp. brevirete, Cephaloziella varians, Odontoschisma macounii, and Cephalozia bicuspidata. II: 1, 3, 6. Common in dry habitats (Philippi, 1973).

SAUTERIA AlPINA (Nees) Nees - II: 8. At the bottom of Scharfreiters near the coast, single thalli on soil in Tomenthypnum-tundra, mixed with Distichium capillaceum, Orthothecium chryseum, Timmia norvegica etc. (Philippi 1973).

*SCapania Cuspiduligera (Nees) Müll.Frib. (gem.) I: 9. At the border of an overgrown spot [119735]. 19. On peat between boulders [119719]. 20. On soil on edge of a spot in spotty tundra[119726]. Associates are Cephaloziella varians, Lophoziopsis polaris, Blepharostoma trichophyllum subsp. brevirete, Schljakovianthus quadrilobus, and Aneura pinguis. The species was reported as rare in Svalbard (Frisvoll \& Elvebakk, 1996), but according to our experience the species is not rare in appropriate sites in Svalbard, but it is never abundant.

*SCAPANia gymnostomophila Kaal. (gem.) - I: 17. Single stems in mats with Preissia quadrata subsp. hyperborea [119740]. Reported as very rare in Svalbard by Frisvoll and Elvebakk (1996), can be rather common in some areas (Konstantinova \& Savchenko, 2012). The species can easily be overlooked because of small size and often occurring as a single plant.

SCAPANIA IRRIGUA (Nees) Nees - The species is represented in one collection preserved in TRH: Frankenhalvøya SV Våtmark (78.6298N, $21.3121 \mathrm{E})$, collected by Rolv Hjelmstad, $69404 / 1$. We refer the second sample from Barents Island collected by Rolv Hjelmstad (N69403) and identified by Frisvoll as S. irrigua to $S$. obcordata. II: 1, 2, 5. Recorded for many sites by Philippi (1973), but he treated the species in very broad sense (including S. curta and 
S. hyperborea). Reported as rare in Svalbard by Frisvoll \& Elvebakk (1996), but as mentioned above the records of these species need to be verified because at least some of them may represent other Scapania species.

*SCAPANia OBCORDATA (Berggr.) S.W.Arnell (gem.) - I: $3,6,8,13,14,16,18,21$. On peat and soil in cracks and niches in banks of streams, on soil between rocks in solifluction slopes, on soil among grasses in tundras on steep slopes, on peat and sandy soil in cracks of dolerite cliffs, sometimes among herbs and in bryophyte cushions in tundras with cryogenic non sorted circles and mud boils [119683]. Not rare. It can dominate in mats with admixture of other hepatics. The most common associates are Blepharostoma trichophyllum subsp. brevirete, Cephaloziella varians, and Lophoziopsis polaris. According to our data $S$. obcordata is rather common in Svalbard in areas with sandstones, argillite and other mostly siliceous rocks e.g. on the eastern coast of Grønfjord (Konstantinova \& Savchenko, 2008).

Schistochilopsis incisa (Schrad.) Konstant. [Lophozia incisa (Schrad.) Dumort.] - II: 1, 5. „An humosen Anrissen, besonders in der Dicranum angustum-Tundra" (Philippi, 1973).

SCHLJAKOVIANTHUS QUADRILOBUs (Lindb.) Konstant. et Vilnet [Barbilophozia quadriloba (Lindb.) Loeske, Orthocaulis quadrilobus (Lindb.) H.Buch] - I: 2, 3, 5, 8, 12, 16, 17, 19, 20. In moist tundra at the base of slopes, on edges of bogs, on peat between boulders, in cracks of cliffs, on banks of streams sometimes in pure mats [119734], but more often mixed with other hepatics, particularly Blepharostoma trichophyllum subsp. brevirete, Cephaloziella varians, Aneura pinguis, Lophoziopsis polaris, and Mesoptychia heterocolpos etc. II: 1, 2, 3, 5, 6, 8, 9. Widespread (Philippi, 1973). One of the most common species in Svalbard. In addition to the typical form f. glareosa occurs sporadically in the studied area [119744].

Sphenolobus minutus (Schreb. ex D.Crantz) Berggr. [Anastrophyllum minutum (Schreb.) R.M.Schust.] - I: 3, 7, 22. On spots in moist tundras at the base of slopes, on cryogenic disturbance of soil in Luzula-grass moss tundra [119689]. The most common associates are Lophozia spp. and Cephaloziella varians. II: 1, 3,5 . Sporadic on cryogenic disturbance of soil mostly in Dicranum angustum-tundras (Philippi, 1973).

Tetralophozia setiformis (Ehrh.) Schljakov [Chandonanthus setiformis (Ehrh.) Lindb.] - II: 3- rare near the top with Racomitrium lanuginosum (Philippi, 1973). Common in Svalbard in areas with block screes.

TRILOPHOZIA QUINQUedentata (Huds.) Bakalin var. QUINQUEDENTATA [Tritomaria quinquedentata (Huds.) H.Buch] - I: 2, 3, 6, 7, 12, 16, 17, 18, 22. On soil among mosses in non sorted circles and between boulders in rocky streams, on small peat hillocks in the dried up beds of streams, in bogs, in niches and crevices in peat banks of streams, among schist outcrops [119674], in pure turf and mats or mixed with other hepatics, more often with Lophoziopsis polaris, Ptilidium ciliare, and Sphenolobus minutus. II: 1, 3, 5, 6. Common, especially in moss tundras (Philippi, 1973). F. gracilis sometimes occurs on bare soil on banks of rivulets and in non sorted circles [119682].

*TRILOPHOZIA QUinquedentata (Huds.) Bakalin var. TURGIDA (Lindb.) Konstant. comb. nov. (Bas. Jungermannia quinquedentata var. turgida Lindb., Kgl. Sv. Vetensk.-Akad. Handl. 23 (5): 59, 1889) - I: 2. In moist tundra, at the base of boulder [119669], with admixture of some shoots of Cephaloziella varians and Lophoziopsis propagulifera.

\section{DISCUSSION}

The compiled list of the hepatics of Barents Island counts 35 species, three subspecies and four varieties. Two species of Lophozia (Lophozia silvicola H.Buch and Lophozia subapiculata R.M.Schust. et Damsh.) are reported for the archipelago for the first time. One of these species (Lophozia silvicola H.Buch) was for a long time treated as a synonym of Lophozia ventricosa (Dicks.) Dumort. (e.g. Paton, 1999) or its variety silvicola (H.Buch) E.W.Jones (Schuster, 1988; Damsholt, 2002) by many authors. Lophozia ventricosa was reported for Svalbard (Frisvoll \& Elvebakk, 1996), but we agree with them that "the reports have to be reconsidered according to an updated taxonomy of the group". Lophozia subapiculata R.M.Schust. et Damsh. is a poorly known taxon that isn't accepted by some authors (e.g. Bakalin, 2005), but we prefer to keep it as species as stated above. The 
occurrence of Preissia quadrata (Scop.) Nees subsp. hyperborea R.M.Schust. was suggested by Frisvoll \& Elvebakk (1996), they state (1.c.: 108) that "The Svalbard plant probably belongs to ssp. hyperborea", but as far as we know there are so far no exact records of this subspecies for Svalbard. This arctic subspecies was described by Schuster in 1985 and its distribution and variation are poorly known (Schuster, 1992). The finding of arctic variety [Lophoziopsis excisa (Dicks.) Konstant. et Vilnet var. elegans (R.M.Schust.) Konstant. et Vilnet] in Svalbard is quite predictable.

Fifteen species and two varieties were previously not reported for the island. Except for Mesoptychia heterocolpos, which is widespread in Svalbard, all hepatics newly found on Barents Island are known as rare or sporadic in Svalbard. Some of these species are very small plants that often occur as single shoots in mats of other bryophytes, e.g. Jungermannia polaris, Lophoziopsis excisa, Mesoptychia collaris, Scapania cuspiduligera, Scapania gymnostomophila, and Scapania obcordata. In our previous studies (Konstantinova \& Savchenko, 2008 a, b, 2012) we have shown that many species that were reported by Frisvoll and Elvebakk (1996) as rare or very rare in Svalbard are more or less widespread in the archipelago, but overlooked because of small size, occurrence as single shoots and problems of identification. Particularly Jungermannia polaris often occurs without gametangia and scattered among other bryophytes. A careful search usually finds at least single plants with perianth and androecia making it possible to identify it correctly whereas identifications of sterile plants lead to misidentifications. Another species newly recorded for the island is Lophoziopsis polaris. It is one of the most common hepatics in the studied area. Several species are represented on the island either wholly or in part by their arctic varieties or subspecies. We particularly referred all collections of Preissia quadrata to subsp. hyperborea based on autoicous inflorescence and characteristic shape of male receptacle (see above). Of four specimens of Mesoptychia heterocolpos we referred three to its arctic variety harpanthoides. We have earlier reported this taxon for Nordaustlandet (Konstantinova \& Savchenko, 2012) where this variety is not rare.
One of the new records for Barents Island is Cephalozia bicuspidata. Frisvoll \& Elvebakk (1996) supposed that the species is rare in Svalbard and even doubted its presence there, stating that "the presence on Svalbard of C. bicuspidata is perhaps not yet absolutely certain". As we mentioned above it is hard to distinguish these two species which are treated as subspecies by several authors (Schuster, 1974), but at least one of the studied specimens with large cells fits well in the description of $C$. bicuspidata. Both C. bicuspidata and C. ambigua are widespread in Svalbard but rare on the island.

We found one species (Clevea hyalina) that previously was not recorded for the island during revision of the Svalbard specimens in TRH. It is a species of calcareous sites that are rare in studied area.

Five species (Arnellia fennica, Marchantia polymorpha subsp. montivagans, Sauteria alpina, Scapania irrigua, and Tetralophozia setiformis) that were reported for the southern part of the Barents Island by Philippi (1973) were not collected in the northern part that was studied by us. Of them Sauteria alpina is a common and widespread hepatic in calcareous areas of Svalbard and its rarity on Barents Island can be explained by the prevalence of magmatic rocks there. Scapania irrigua was reported by Philippi (1.c.) for Barents Island in very broad sense, as a collective species including Scapania curta and $S$. hyperborea. In the Arctic all these taxa are often misidentifications for S. obcordata. Arnellia fennica is relatively rare, a strictly calciphilous species that occurs sporadically in Svalbard. There are very few appropriate sites for it in the area studied by us. This is also true for Marchantia polymorpha subsp. montivagans that in Svalbard is mainly restricted to areas under bird cliffs, which do not occur in the studied part of the island. Tetralophozia setiformis was collected only once by Philippi (1973). This species is restricted to areas with boulder screes that as well are not represented in area studied by us.

The most common and abundant hepatics in the northern part of the island are arctic (Lophoziopsis polaris, Scapania obcordata, and Blepharostoma trichophyllum subsp. brevirete), arctic montane (Cephaloziella varians) and arctic boreomontane (Ptilidium ciliare and 
Trilophozia quinquedentata) species. Two of them (Lophoziopsis polaris and Scapania obcordata) were previously reported to be rare in Svalbard (Frisvoll \& Elvebakk, 1996), but we found in our previous studies (Konstantinova \& Savchenko, $2008,2012)$ that both species are widespread and locally abundant in Svalbard.

Several hepatics widespread and common in Svalbard e.g. Barbilophozia hatcheri and Sphenolobus minutus were only recorded a few times in this study. It can be explained both by time constraints of the field trip and the restricted area studied.

\section{ACKNOWLEDGEMENTS}

We thank Lars Söderström and Xiaolan HeNygren as well as an anonymous reviewer for valuable comments on the manuscript. We are very grateful to Anders Hagborg for the English correction and some valuable suggestions. This research has been partly financially supported by the Ministry of Economical Development and Trade of the Russian Federation and the Russian Foundation for Basic Researches (grant N 15-29-02662). The study of Frisvoll's collection in Trondheim was supported by the Research Council of Norway, project no. 246728/E10

\section{REFERENCES}

Arnell, S. \& Mårtensson, O. 1959. A contribution to the knowledge of the bryophyte flora of W. Spitsbergen and Kongsfjorden (King's Bay, $79^{\circ} \mathrm{N}$.) in particular. Ark. Bot. 4(6): 105-164.

Bakalin, V. A. 2005. Monographicheskaja obrabotka roda Lophozia (Dum.) Dum. s. str. Nauka, Moscow (in Russian).

Bakalin, V. A. 2016. Notes on Lophozia VIII. The lectotypification of Lophozia longiflora (Nees) Schiffn. (Lophoziaceae, Hepaticae). Herzogia 29: 635-642. https://doi.org/10.13158/heia.29.2.2016.635

Damsholt, K. 2002. Illustrated Flora of Nordic liverworts and hornworts. Nordic Bryological Society, Lund. 840 pp.

Frisvoll, A. A. \& Elvebakk, A. 1996. Bryophytes. In: Elvebakk, A. \& Prestrud, P. (eds). A catalogue of Svalbard plants, fungi, algae and cyanobacteria. Part. 2. Norsk Polarinst. Skr. 198: 57-172.

Karczmarz, K. \& Święs, F. 1990. Bryophytes collected in arctic tundra of the eastern slopes of Activekammen (Western Spitsbergen) in 1987-1988. In: Repelewska-Pekalowa, J. \& Pekala, K. (eds), Polar session, Periglacial phenomena of western Spitsbergen. Lublin, Poland-April 1990. Wyprawy
Geograficzne na Spitsbergen. Maria Curie-Sklodowska University, Lublin. Pp. 175-183.

Konstantinova, N. A., Vilnet, A. A. \& Ștefănut, S. 2014. On the distribution and variability of Bucegia romanica Radian. Arctoa 23: 137-144. https:// doi.org/10.15298/arctoa.23.11

Konstantinova, N. A. \& Koroleva, N. E. 2003. On some dwarf forms of hepatics new for Spitzbergen archipelago. In: Matishov, G. G. \& Tarasov, G. A. (eds). Complex investigations of Spitzbergen nature 3. Pp. 156-161 and pp. 255-256. Kola Science Centre, Apatity (in Russian with English summary).

Konstantinova, N. A. \& Savchenko, A. N. 2006. Findings of some rare hepatics in Spitzbergen in western coast of Bockfjorden. In: Matishov, G. G. \& Tarasov, G. A. (eds). Complex investigations of Spitzbergen nature 6. Pp. 330-336 and 435. Kola Science Centre, Apatity (in Russian with English summary).

Konstantinova, N. A. \& Savchenko, A. N. 2008a. Contribution to the hepatic flora of Svalbard. Lindbergia 33:13-22.

Konstantinova, N. A. \& Savchenko, A. N. 2008b. Hepatics. In: Koroleva, N. E., Konstantinova, N. A., Belkina, O. A., Davydov, D. A., Likhachev, A. Y., Savchenko, A. N. \& Urbanavichene, I. N. Flora and vegetation of Gronfjord area (Spitsbergen archipelago). Pp. 54-80. K \& M. Apatity (in Russian with English summary).

Konstantinova, N. A. \& Savchenko, A. N. 2012. Contribution to the Hepatic flora of the Nordaustlandet (Svalbard). I. Hepatics of the north coast of Murchison Fjorden. Polish Botanical Journal 57(1): 181-195.

Paton, J.A. 1999. The liverwort flora of the British Isles. Colchester.

Philippi, G. 1973. Moosflora und Moosvegetation des Freeman-Sund-Gebietes (Südost-Spitzbergen). In: Budel, J. \& Wirthman, A. (eds.). Ergebn. Stauferland-exped. 1959/60 (7): 1-83.

Rejment-Grochowska, I. 1967. Contribution to the hepatic flora of the north coast of Hornsund (S.W. Svalbard). Au. Soc. Bot. Polon. 36: 531-544. https://doi.org/10.5586/asbp. 1967.050

Schuster, R. M. 1969. The Hepaticae and Anthocerotae of North America east of the hundredth meridian. 2. Columbia University Press, New York. 1062 pp.

Schuster, R. M. 1985. Some new taxa of Hepaticae. Phytologia 57(6): 408-414.

Schuster, R. M. 1988. The Hepaticae of South Greenland. Nova Hedwigia 92: 1-255.

Schuster, R. M. 1992. The Hepaticae and Anthocerotae of North America east of the hundredth meridian. 6. Columbia University Press, New York. 937 pp.

Schuster, R. M. \& Damsholt, K. 1974. The Hepaticae of West Greenland from ca. $66^{\circ} \mathrm{N}$ to $72^{\circ} \mathrm{N}$. Meddel. Gronland 199(1): 1-373.

Söderström, L., Hagborg, A., von Konrat, M., Bartholomew-Began, Sh., Bell D., Briscoe, L., Brown, E., Cargill, D. Ch., Costa, D. P., Crandall-Stotler, 
B. J., Cooper, E. D., Dauphin, G., Engel, J. J., Feldberg, K., Glenny D., Gradstein, S. R., He X.L., Heinrichs, J., Hentschel, J., Ilkiu-Borges, A. L., Katagiri, T., Konstantinova, N. A., Larrain, J., Long, D. G., Nebel, M., Pócs, T., Puche, F., ReinerDrehwald, E., Renner, M. A. M., Sass-Gyarmati, A., Schäfer-Verwimp, A., Moragues, J. G. S., Stotler, R. E., Sukkharak, Ph., Thiers, B. M., Uribe, J., Váňa, J., Villarreal, J. C., Wigginton, M., Zhang, L., Zhu, R.-L. 2016. World checklist of hornworts and liverworts. PhytoKeys 59: 1-828. https://doi. org/10.3897/phytokeys.59.6261

Święs, F. \& Karczmarz, K. 1991a. Bryophytes collected in arctic tundra of the Chamberlin region (Western Spitsbergen) in 1987 and 1988. Ann. Univ. Mariae Curie-Sklodowska, Sect. C, Biol. 46: 29-43.

Święs, F. \& Karczmarz, K. 1991b. Bryophytes collected in arctic tundra of the Logne region
(Western Spitsbergen) in 1988. In RepelewskaPekalowa, J. \& Pekala, K. (eds.): Polar session. Arctic environment research. Lublin, Poland April 1991. Wyprawy Geograficzne na Spitsbergen. Pp. 145-162. Maria Curie-Sklodowska Univ., Lublin. Święs, F. \& Karczmarz, K. 1993. Bryophytes collected in arctic tundra of the Lyellstranda region (Western Spitsbergen) in 1987 and 1988. In: Repelewska-Pekalowa, J. \& Pekala, K, (eds.). XX Polar symposium. Man impact on polar environment. Lublin, Poland June 3-5, 1993. Pp. 249-271. Vilnet, A. A., Konstantinova, N. A. \& Troitsky, A. V. 2012. Molecular phylogeny and systematics of the suborder Cephaloziineae with special attention to the family Cephaloziaceae s.1. (Jungermanniales, Marchantiophyta). Arctoa 21: 113-132. https:// doi.org/10.15298/arctoa.21.11 
116 Folia Cryptog. Estonica 